\title{
Teologi Keselamatan Injil Lukas 19:1-10 dan Implikasinya bagi Pendidikan Agama Kristen
}

\author{
Hasudungan Sidabutar \\ Institut Agama Kristen Negeri Kupang \\ email: hasudungan090584@gmail.com \\ Rinto Hasiholan Hutapea \\ Institut Agama Kristen Negeri Palangka Raya \\ email: rintohutapea81@gmail.com
}

\begin{abstract}
This study explores the concept of salvation. The study aims to answer the problem of differences in the concept of safety that students have in schools. The research method used in this research is qualitative research with a literature approach. The results of the research are as follows: First, the salvation of the Old Testament to the New Testament is the salvation of God Himself. Second, man is not saved by his own efforts but rather the Work of God, who is active in the work of salvation. Third, the Gospel of Luke contains a universal theology of salvation. Fourth, salvation does not look at boundaries, but salvation from God through Jesus Christ breaks through the boundaries made by humans. Fifth, human judgment is not the determinant of salvation but only God Himself should place it. Sixth, the concept of salvation in the Gospel of Luke 19: 1-10 can be considered in Christian Religious Education learning materials in schools.
\end{abstract}

Keywords: Theology of Salvation; Luke; Christian Education

\begin{abstract}
Abstrak
Penelitian ini menggali konsep tentang keselamatan.Tujuan penelitian ini untuk menjawab permasalahan perbedaan konsep keselamatan yang dimiliki oleh peserta didik di sekolah. Metode penelitian yang digunakan dalam penelitian ini adalah penelitian kualitatif dengan pendekatan kepustakaan. Hasil penelitian adalah sebagai berikut: Pertama, keselamatan dari Perjanjian Lama hingga Perjanjian Baru adalah keselamatan dari Allah Sendiri. Kedua, manusia tidaklah selamat atas usahanya sendiri, tetapi lebih kepada karya Allah yang bertindak aktif dalam karya keselamatan. Ketiga, Injil Lukas memuat teologi keselamatan yang bersifat Universal. Keempat, keselamatan tidak memandang batasan, tetapi keselamatan dari Allah melalui Yesus Kristus menerobos batasan-batasan yang dibuat oleh manusia. Kelima, penilaian manusia bukanlah penentu terhadap keselamatan melainkan hanya Allah sendirilah yang patut menempatkan keselamatan itu. Keenam, konsep keselamatan dalam Injil Lukas 19:1-10 dapat dipertimbangkan dalam materi pembelajaran Pendidikan Agama Kristen di sekolah.
\end{abstract}

Kata Kunci: teologi keselamatan; Lukas; Pendidikan Agama Kristen 


\section{PENDAHULUAN}

Topik tentang keselamatan merupakan bagian penting dalam diskusidiskusi kehidupan umat manusia. Dalam diskusi-diskusi tersebut muncul berbagai pandangan tentang keselamatan. Termasuk perdebatan dikalangan umat beragama yang menawarkan klaim akan keselamatan. Umat beragama menyadari adanya sebuah realitas lain di luar realitas dirinya yang ia hadapi di dunia fana ini. Realitas tersebut adalah sorgawi yang kekal. Karena kesadaran akan realitas ini maka ajaran atau teologi keselamatan untuk mencapai sorga itu bermunculan.

Di kalangan Kristen Protestan membagi ajaran atau teologi keselamatan itu secara tajam ke dalam dua mazhab yaitu mazhab Calvinis dan mazhab Arminius. ${ }^{1}$ Mazhab Calvinis berpandangan bahwa Allah memilih dan menentukan atau menetapkan secara sepihak mengenai keselamatan seseorang dengan mazhab Arminian yang mengajarkan bahwa keselamatan dicapai melalui upaya gabungan dari Allah (yang mengambil inisiatif) dan manusia (yang harus menanggapi) respons manusiamenjadi faktor yang

\footnotetext{
${ }^{1}$ Demsy Jura, "Kajian Soteriologi Dalam Teologi Universalisme, Calvinisme Dan Armenianisme Serta Kaitannya Dengan Pembelajaran Pendidikan Agama Kristen.," SHANAN: Jurnal Pendidikan Agama Kristen 1 No. 2 (n.d.).
}

menentukan.Konsekuensi pandangan

Calvinis adalah Allah berdaulat penuh atas keselamatan. Jadi tidak tergantung pada manusia yang memang tidak mampu, sehingga keselamatan tidak bisa hilang. Sementara Arminius memiliki pandangan bahwa kasih karunia diberikan, tapi manusia menentukan menerima atau tidak, sehingga keselamatan bisa hilang.

Secara sederhana sebagai penengah pandangan di atas, ada juga konsep keselamatan merupakan anugerah dari Allah. Dessy Handayani mengungkapkan bahwa keselamatan adalah anugerah Allah, manusia hanya dapat menerima keselamatan dari Allah hanya melalui iman, bukan karena perbuatan. ${ }^{2}$ Setelah menerima keselamatan dengan cara demikian, manusia harus mengerjakan keselamatan itu didalam kehidupan melalui perbuatan-perbuatan yang manusia lakukan dan kerjakan.

Berdasarkan pandangan di atas, menarik untuk ditelusuri bagaimana teologi keselamatan bisa berbeda di kalangan sesama Kristen. Apa itu keselamatan? Bagaimana implikasi praktis keselamatan itu dalam kehidupan umat? Kedua pertanyaan ini merupakan pertanyaan penting berkaitan dengan teologi keselamatan dan menjadi hal

\footnotetext{
${ }^{2}$ Dessy Handayani, "Tinjauan Teologis Konsep Iman Dan Perbuatan Bagi Keselamatan," EPIGRAPHE: Jurnal Teologi dan Pelayanan Kristiani 1, no. 2 (2018): 91.
} 
pokok yang dibahas dalam tulisan ini. Teologi keselamatan telah banyak dibahas oleh para ahli. Semua memberikan pandangan yang berbeda. Ada yang membedakan keselamatan dalam perjanjian lama dengan keselamatan yang ada dalam perjanjian baru. Diantaranya adalah teologi Alkitab modern yang menekankan ketidaksinambunganantara perjanjian lama dengan perjanjian baru.Tetapi ada juga yang menghubungkan keselamatan dalam Perjanjian lama dan perjanjian baru. Misalnya teolog seperti Bengel, Beck dan Von Hofmann yang menerangkan hubungan antara kedua perjanjian dalam arti rencana keselamatan Allah yang lengkap dan berkesinambungan.

Permasalahan lain tentang konsep keselamatan ialah terjadi di kalangan siswa di sekolah. Materi keselamatan menjadi salah satu bagian dari pembelajaran Pendidikan Agama Kristen di sekolah. Peran guru dalam menyampaikan materi keselamatan secara teologis menjadi bagian penting untuk mengatasi perbedaan konsep dalam diri siswa. Perbedaan konsep ini dapat terjadi oleh karena informasi yang diterima berasal dari sumber yang berbeda juga. Siswa ada yang memahami kalau keselamatan itu diterima dan tidak bisa hilang. Ada juga siswa yang memahami kalau keselamatan itu bisa hilang jika tidak dijaga. Perbedaan konsep keselamatan dalam diri siswa tentu perlu diluruskan. Untuk itu, peran guru Pendidikan Agama Kristen sangat dibutuhkan.

Dalam tulisan ini akan membahas tentang Teologi Keselamatan yang terdapat dalam Injil Lukas. Lukas yang memfokuskan keselamatan dari Yesus sebagai Juru selamat. Yesus sebagai jalan keselamatan bagi semua manusia. Istilah keselamatan yang dipakai dalam Injil

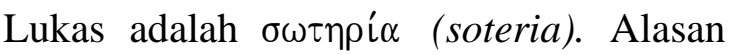
pemilihan teks Lukas 19:1-10 sebagai bahan kajian untuk menjawab permasalahan-permasalahan yang dibahas di atas adalah teks Lukas memberikan gambaran yang sederhana dan mudah dipahami terkait konsep keselamatan di banding dengan teks-teks lain.

\section{METODE PENELITIAN}

Penelitian ini menggunakan metode penelitian kualitatif dengan pendekatan kepustakaan. Peneliti akan menggali sumber-sumber kepustakaan terkait topik pembahasan dalam penelitian ini. Sumbersumber yang dimaksud berasal dari bukubuku dan jurnal-jurnal ilmiah. Dari hasil pengumpulan materi tersebut, peneliti akan menyusun konsep-konsep teori secara sistematis dan melakukan kajian analisis 
terhadapnya. Kesimpulan diperoleh dari kajian analisis terhadap teks Lukas 19:1-10 dengansistematika: pembahasan konsep keselamatan Perjanjian Lama, konsep keselamatan Perjanjian Baru, dan Eksposisi konsep keselamatan Injil Lukas.

\section{HASIL DAN PEMBAHASAN}

\section{Hakekat Keselamatan}

Pembahasan pada bagian ini menyajikan hakekat dari keselamatan itu sendiri. Hakekat keselamatan pada bagian ini mengandung unsur pengertian keselamatan. Secara etimologi, keselamatan berasal dari bahasa Ibrani yesyua dan Yunani soteria, yang berarti tindakan atau hasil dari pembebasan atau pemeliharaan dari bahaya atau penyakit, mencakup keselamatan, kesehatan, dan kemakmuran. ${ }^{3}$ Sementara itu Carlson menguraikan makna keselamatan sebagai berikut: keselamatan adalah usaha ilahi yang berdasarkan kasih Allah bagi orangorang yang terhilang dalam dosa. ${ }^{4}$ Rencana keselamatan perlu karena dua fakta: pertama, sekalian manusia terhilang. Kerusakan moral manusia pada umumnya dan kekerasan hati yang ada dalam setiap pribadi. Kedua, kasih Allah yang tidak berubah mendorong Allah untuk bertindak.

${ }^{3}$ J. L. Haldenguis, Ensiklopedia Alkitab Masa Kini Jilid II (Jakarta: Yayasan Komunikasi Bina Kasih, 2008), 376.

${ }^{4} \mathrm{G}$. Raymond Carlson, Keselamatan (Malang: Gandum Mas, 1983), 3.
Ketika dosa merajalela dan manusia di mana-mana telah berpaling dari Allah, ketika hati-Nya yang penuh kasih menjadi sangat pedih karena kejahatan dan ketegaran manusia, Allah datang untuk menyelamatkan manusia.

Konsep keselamatan erat kaitannya dengan anugerah Allah yang membebaskan umat manusia yang berdosa. Keselamatan yang membebaskan umat manusia dari dosa merupakan karya Allah dalam diri Yesus yang datang kedunia. Robert mempertegas, Yesus datang ke dunia ini sebagai AnakManusia dan juga disebut sebagai AnakAllah yang datang untuk melakukan misi penyelamatan manusia yang berdosa. ${ }^{5}$ Tidak dapat dipungkiri bahwa dosa atau kejahatan sudah ada sebelum manusia diciptakan oleh Allah. Sebelum Adam dan Hawa ada, iblis sudah ada dan dia adalah bapa dari segala pendusta dan pendosa. Dalam Alkitab dicatat secara jelas bahwa manusia di taman Eden, iblislah yang membujuk manusia untuk melanggar perintah Allah sampai manusia itu sendiri berbuat dosa karena bujukkan Iblis.

Kejatuhan dalam dosa membuat manusia terpisah dari Allah dan kehilangan kemuliaan Allah. Alam semesta menjadi terkutuk oleh murka

\footnotetext{
${ }^{5}$ Robert Pangaribuan, "Menyikapi Perbedaan Pandangan Christology from Above and Christology from Below," SOTIRIA: Jurnal Teologi dan Pelayanan Kristiani 2, no. 1 (2019): 17-20.
} 
Allah. Allah menjadi Allah yang transenden atau jauh. Tidak satu manusia yang dapat mendekat kepada-Nya (Kejadian 3). Kejatuhan manusia ke dalam dosa diartikan sebagai pemberontakan manusia yang menentang kedaulatan dan otoritas Allah. Karena manusia telah jatuh dalam dosa, maka manusia membutuhkan keselamatan. Terkait itu, keselamatan merupakan rencana besar Allah yang telah dimulai sejak penciptaan. ${ }^{6}$ Untuk itu, kejatuhan manusia dalam dosa berhak memperoleh anugerah keselamatan. Dalam Alkitab istilah keselamatan ini disebut soteriologi. Secara singkat soteriologi dapat diartikan sebagai ajaran tentang keselamatan. Soteriologi dalam bahasa Yunani berasal dari dua suku kata yaitu soteria yang berarti keselamatan dan logos yang berarti firman, perkataan atau ajaran.

Konsep keselamatan juga sangat jelas dimuat dalam teks Alkitab. Dalam Efesus 2:8-9 memuat konsep keselamatan sebagai anugerah Allah dan bukan merupakan usaha manusia. Menurut David Eko Setiawan, pada dasarnya manusia tidak dapat menyelamatkan dirinya sendiri. ${ }^{7}$ Manusia membutuhkan anugerah

\footnotetext{
${ }^{6}$ Sonny Eli Zaluchu, Biblical Theology: Pembahasan Metodologi Dan Pendekatan Biblika Dalam Membangun Teologi PL Dan PB Yang Alkitabiah (Semarang: Golden Gate Publishing, 2017), 100.

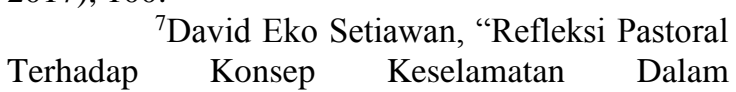

dari Allah untuk diselamatkan. Hal ini disebabkan oleh keberdosaan manusia. Keberdosaannya itulah yang membuatnya tidak dapat menyelamatkan dirinya sendiri.

Dengan demikian jelas bahwa istilah soteriologi merupakan istilah Alkitab yang mengarahkan kita ke dalam pembahasan tentang keselamatan melalui Yesus Kristus. Dengan kata lain, soteriologi merupakan ilmu yang mempelajari tentang prinsip-prinsip keselamatan dalam Yesus Kristus. Keselamatan menjadi hal yang sangat penting bagi semua manusia karena berhubungan dengan kekekalan, serta hidup dan mati manusia di masa yang akan datang.

Keselamatan Dalam Perjanjian Lama

Kitab Perjanjian Lama (PL) menyajikan konsep keselamatan sebagai berikut. "Keselamatan" digunakan untuk menerjemahkan kata-kata bahasa Ibrani yang berbeda di antaranya adalah "yesua" dari bentuk yasa yang ditemukan hanya dalambentuk niph'al dan hiph'il. Kata niph'il mempunyai arti "menyelamatkan" akar yasa mempunyai arti yang fundamental yaitu menyeberangkan, memperluas yang membawa makna

Universalisme Ditinjau Dari Soteriologi Kristen," FIDEI: Jurnal Teologi Sistematika dan Praktika 1, no. 2 (2018): 250-269. 
membebaskan. Sebaliknya kata tekanan, kurungan, dan ketidakleluasaan membawa makna terimpit dan membutuhkan pembebasan. Nama yang tepat diambil dari akar yesua, juru selamat adalah terjemahan dari hiph'il partisif dari yasa yaitu masia. Contoh Hak. 3:9,15; Yes. 19:20; 43:11. Kata Ibrani yang lain untuk mengungkapkan ide menyelamatkan atau keselamatan dalam Kej. 19:19; 45:7; 50:20, Kel. 1:17-18; Bil. 22:33; Ul. 20:16; Hak. 8:19; 1 Sam. 12:21;19:11, II Sam. 19:9; Ayub 2:6, 20:20, Yer. 51:6,45; Yeh $3: 18 ; 18: 27) .{ }^{8}$ Sehingga dapat disimpulkan bahwa kata yasa adalah kebebasan dari suatu yang mengikat atau membatasi dan kemudian berarti pembebasan. Pembebasan atau memberikan keluasan dan kelapangan kepada sesuatu. Kata yasa dipakai sebanyak 31 kali dalam kitab PL.

Selanjutnya, kata yang terutama disebut ga'al yang artinya menebus. Penebusan lahir sebagai pembebasan dari kesengsaraan, tekanan, kematian dan penawanan (Mesir dan Babel). Hal ini tidak biasa dalam PL untuk datang melalui penebusan dari dosa (tapi Lih. Maz. 130:8). Hal ini khususnya dalam Deutero Yesaya bahwa Allah sendiri dihadirkan sebagai penebus Israel (Yes. 41:14; 43:14; 44:6, 24 dll) disebutkan sebanyak 13 kali. Di luar kitab Yesaya Allah dipanggil go'el

${ }^{8}$ Alan Richaeson, The Interpreter Dictionary of The Bible (New York: Abingdon Press, 1962), 169. hanya sebanyak 4 kali.

$$
\text { Septuaginta (LXX) merupakan }
$$

terjemahan tertua dan terpenting dari PL ke dalam bahasa Yunani.LXX memberikan bahasa Ibrani yang berbeda tentang "keselamatan" dengan kata " $\sigma \omega \zeta \varepsilon \imath v . "$ Kemudian beberapa perbedaan yang tersirat hilang dalam bahasa Yunani. Keselamatan " $\sigma \omega \tau \eta \rho \iota \alpha "$ atau

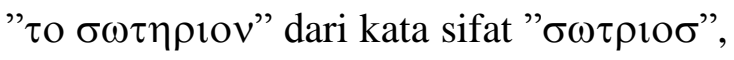
keselamatan; dalam bahasa Yunani berbentuk jamak neuter " $\tau \alpha \sigma \omega \tau \eta \rho \imath \alpha "$ bisa berarti membebaskan. ${ }^{9}$ Dengan demikian, keselamatan mengandung arti yang membebaskan.

\section{Keselamatan Dalam Perjanjian Baru}

Kitab Perjanjian Baru (PB) menyajikan kata soteria sebagai kata keselamatan. Soteria adalah kata yang dipakai dalam bahasa Yunani untuk menunjuk kepada kata "keselamatan" yang ditemukan sebanyak 46 kali dalam PB. Sementara itu kata to soterion muncul sebanyak 4 kali (Luk. 2:30; 3:6 Kis. 28:28. Ef. 6:17). Kata sifat soterios muncul hanya satu kali dalam Tit. 2:11

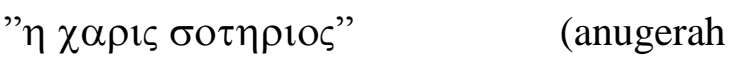
keselamatan). Juruslamat disebut dengan $\sigma \omega \tau \eta \rho$ sebuah kata yang muncul dalam kitab injil hanya pada Lukas 1: 47; 2:11;

${ }^{9}$ Georg Fohrer, Theological Dictionary of The New Testament (Michigan: Grand rapids, 1971), 970. 
Yoh. 4:42 dan dalam Kisah Para Rasul hanya pada pasal 5:31; 13:23. Dalam tulisan Paulus muncul dua kali yaitu Ef. 5:23; Fil. 3:20. Kata ini ditemukan 10 kali dalam surat-surat pastoral. Terpisah dari keterangan yang 6 ini hanya dua bagian yang berbicaratentang Allah yaitu

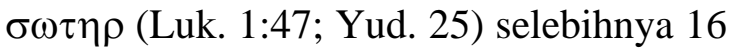
contoh merujuk kepada Kritus sebagai $\sigma \omega \tau \eta \rho$. Contoh-contoh dalam 2 Pet. 1:1; 1 Yoh. 4:14, bersamaan dengan 4 contoh dalam 2 Petrus melengkapi hitungan penggunaan kata " $\sigma \omega \tau \eta \rho "$ dalam Perjanjian Baru.

Hal ini akan dituliskan bahwa penggunaan kata " $\sigma \omega \tau \eta \rho "$ dalam Perjanjian Baru lebih banyak yang kemungkinan ditulis setelah kematian Paulus. Tetapi hal itu bukanlah jelas apakah beberapa kesimpulan akan ditarik dari fakta ini dimana hal ini barangkali dipengaruhi oleh gnostik sehingga gelar “ $\sigma \omega \tau \eta \rho "$ dipergunakan pada Kristus. ${ }^{10}$

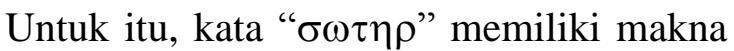
keselamatan melalui karya Kristus.

\section{Injil Lukas}

Kitab Lukas adalah salah satu kitab Sinoptik yang ditulis antara tahun 75-90 M. Hal ini bisa diketahui dari isi injil

\footnotetext{
${ }^{10}$ Richaeson, The Interpreter Dictionary of The Bible, 169.
}

Lukas yang berbicara tentang penghancuran Kota Yerusalem. Orang Kristen di Yerusalem dan sekitarnya mengerti kata-kata Yesus dalam nubuatNya, yang diartikan bahwa mereka harus mengungsi pada waktunya dari kota yang ditimpa kebinasaan. Selain itu juga injil Lukas memakai kitab Markus sebagai salah satu sumber penulisan kitabnya. Maka penulisan Lukas adalah setelah penulisan Markus. ${ }^{11}$ Penulis Injil Lukas adalah Lukas. Pendapat ini dikemukakan dalam tradisi mula-mula. Dia adalah seorang tabib (hal ini ditulis Paulus dalam Kol 4:14) yang berpendidikan dan menjadi kawan seperjalanan Paulus (dalam Filemon 24). Dia berasal dari bangsa nonYahudi. Dalam 2 Tim. 4:11 Paulus menuliskan kata-kata yang menyentuh "hanya Lukas yang tinggal dengan aku." Hal ini sesuai dengan tradisi kristen yang paling tua bahwa Lukas dokter yang dikasihi itu tetap menjadi kawan sekerja paulus yang setia sampai akhir.

Lukas banyak memakai banyak bahan yang digabung dari Matius dan Markus. Hal tersebut muncul sebagai kisah-kisah mengenai masa kanak-kanak (1-2), mujizat, pertobatan, cerita mengenai Herodes, dan kisah penampakan Yesus

${ }^{11}$ M. E. Duyverman, Pembimbing Ke Dalam Perjanjian Baru (Jakarta: BPK Gunung Mulia, 2002), 55-56. 
yang bangkit. Pada kisah yang terdapat di dalam injil Lukas, terdapat juga kisahkisah perumpamaan yang sering terdapat dalam kisah di Matius dan Markus. Injil Lukas dan Injil Yohanes sering dikatakan sebagai kisah yang banyak persamaan seperti pribadi Yudas, pribadi Maria dan Marta, pribadi Hanas, hubungan erat antara penangkapan ikan ajaib dan pelantikan Petrus, penghianatan Yudas yang diperkenalkan sebagai karya Iblis, serta wajangan Yesus pada waktu perjamuan. Injil Lukas mengolah tradisi dengan sangat khas. Ia berusaha menyusun narasi yang teratur dengan susunan yang terencana secara rapi. Dalam Injil Lukas, kosakata di injil Lukas terlihat sangat khas dan kaya dalam seluruh Perjanjian Baru. Bahasa Yunaninya jauh lebih bermutu daripada yang dipakaioleh Markus. Lukas sering memakai semitisme yaitu gaya bahasa Yahudi. Karakteristik Injil Lukas labih baik, Lukas berusahan menulis dengan jelas serta menutup dengan suatu kesimpulan. $^{12}$

Teologi Keselamatan Menurut Lukas

Teologi keselamatan dalam injil Lukas mempunyai posisi yang sentral. Dimana Lukas menuliskan bahwa Keselamatan berasal dari kasihKristus

\footnotetext{
${ }^{12}$ Stefan Leks, Tafsir Injil Lukas (Yogyakarta: Kanisius, 2003), 21-23.
}

yang mengampuni. ${ }^{13}$ Pengajaran Kristus, pekerjaan-Nya, dan juga berkat melalui Dia. Seperti yang dituliskan oleh J. L. Haldenguys bahwa ada ciri khusus dari injil Lukas yaitu: pertama, injil Lukas khusus menekankan bahwa Yesus adalah Juruselamat illahi dalam arti universal. Yesus menawarkan pengampunan dan penebusan secara bebas kepada semua orang. Tidak tergantung pada ras, seks atau jasa. Poin ini juga menjadi materi penting dalam Pendidikan Agama Kristen. Dimana guru maupun siswa di sekolah dapat mengimplementasikan prinsip kebenaran ini, yaitu semua orang memiliki kesempatan untuk memperoleh pengampunan dan penebusan.

Keselamatan ditawarkan kepada orang Samaria (9:52-56; 10:30-37, 17:1119) dan non-Yahudi $(2: 32 ; 3: 6,8 ; 4: 25-27$; $7: 9 ; 10: 124: 47)$ maupun kepada orang Yahudi $(1: 33 ; 2: 10$, dsb), kepada wanita maupun pria, orang berdosa, pemungut cukai $(3: 12 ; 5: 27-32 ; 7: 37-50 ; 19: 2-10$; 23:43), tetapi juga kepada orang terhormat (7:36; 11:37; 14:1), kepada orang miskin $(1: 53 ; 2: 7 ; 6: 20 ; 7: 22)$ maupun kepada orang kaya (19:2; 23:50). Kedua, Lukas adalah menekankan kenyataan bahwa

\footnotetext{
${ }^{13}$ Iswara Rintis Purwantara, "Kritik Hermeneutis Terhadap Interpretasi Soteriologis Perumpamaan Tentang Anak Yang Hilang Dalam Lukas 15:11-32," Prudentia: Jurnal Teologi dan Pendidikan Kristiani 1, no. 1 (2018).
} 
Yesus adalah Juru Selamat yang mempunyai kuasa illahi untuk menyembuhkan baik nyawa maupun tubuh. Keselamatan Juru Selamat adalah keselamatan meliputi segala sesuatu, untuk saat ini dan selama-lamanya.

Keselamatan juga dapat dilihat dalam injil Lukas dan Kisah Para Rasul. Dimana kedua kitab ini ditulis oleh satu orang. Lukas 19:9, ketika Yesus mengunjungi Zakeus, Yesus berkata "hari ini keselamatan datang di dalam rumah ini" walaupun Zakheus adalah seorang berdosa. Yesus menguasai keselamatan melalui perkataan dan perbuatan-Nya. Dalam narasi yang lain, Yong dalam Frans Setyadi menguraikan bahwa melalui pelayanan-Nya, Yesus sebagai penerima keramahan itu, pada waktu yang sama menjadi orang yang menyatakan dan mempersonifikasikan keramahan Allah yang membebaskan. ${ }^{14} \mathrm{Hal}$ ini dapat dilihat dalam pertemuan Yesus dengan Zakheus. Pertemuan Yesus dengan Zakheus menggambarkan posisi Yesus adalah tamu. Namun pada akhirnya, Yesus digambarkan sebagai tuan rumah yang menunjukkan keramahan Allah, sehingga menghasilkan transformasi kepada Zakheus. Dengan demikian keselamatan datang dalam rumah

\footnotetext{
${ }^{14}$ Frans Setiadi Manurung, "Teologi Keramahan Allah: Sebuah Pembacaan Kristologi Lukas," Gema Teologika 3, no. 2 (2018): 185.
}

tersebut.

Kisah Para Rasul menggunakan sodzo dan soteria. Dalam Kis. 7:25 soteria berarti kemungkinan bahwa Musa akan menebus orang-orang Israel. Kis. 27:34 menggunakan istilah dalam pengertian sekuler untuk menjelaskan penyelamatan Paulus dari kecelakaan kapal. Sebaliknya kata ini selalu membawa ide yang dalam tentang keselamatan eskatologi. Soteria dikumandangkan sebagai kata keselamatan (4:12, 13:26,47, diperagakan setelah Yes. 49:6 yang juga muncul dalam Luk. 2:32). Keselamatan dilakukan dalam pengampunan atas dosa-dosa.Walaupun saat ini hal itu bisa digenapi pada masa yang akan datang (4:12). Pemberitaan adalah salah satu jalan keselamatan (Luk $16: 17) .^{15}$

\section{Eksposisi Lukas 19:1-9}

Sesuai dengan Judul tulisan ini, dimana mengkhususkan tulisan ini dalam Lukas 19:1-9 tentang Zakheus.

19:1 Yesus masuk ke kota Yerikho dan berjalan terus melintasi kota itu.

19:2 Di situ ada seorang bernama Zakheus, kepala pemungut cukai, dan ia seorang yang kaya.

19:3 Ia berusaha untuk melihat orang apakah Yesus itu, tetapi ia tidak berhasil karena orang banyak, sebab badannya

\footnotetext{
${ }^{15}$ Haldenguis, Ensiklopedia Alkitab Masa Kini Jilid II, 376.
} 
pendek.

19:4 Maka berlarilah ia mendahului orang banyak, lalu memanjat pohon ara untuk melihat Yesus, yang akan lewat di situ.

19:5 Ketika Yesus sampai ke tempat itu, Ia melihat ke atas dan berkata: "Zakheus, segeralah turun, sebab hari ini Aku harus menumpang di rumahmu."

19:6 Lalu Zakheus segera turun dan menerima Yesus dengan sukacita.

19:7 Tetapi semua orang yang melihat hal itu bersungut-sungut, katanya: "Ia menumpang di rumah orang berdosa."

19:8 Tetapi Zakheus berdiri dan berkata kepada Tuhan: "Tuhan, setengah dari milikku akan kuberikan kepada orangmiskin dan sekiranya ada sesuatu yang kuperas dari seseorang akan kukembalikan empat kali lipat."

19:9 Kata Yesus kepadanya: "Hari ini telah terjadi keselamatan kepada rumah ini, karena orang ini pun anak Abraham.

19:10 Sebab Anak Manusia datang untuk mencari dan menyelamatkan yang hilang."

Zakeus seorang pemungut cukai adalah orang kaya. Lukas menulis juga tentang orang kaya. Dimulai dari 1:53 yang berbunyi: “... dan menyuruh orang yang kaya dengan tangan hampa". Kebahagiaan kepada orang miskin pasal 6:20 adalah salah satu dari ucapan bahagia, kemungkinan berasal dari sumber Q (bnd. Mat 5:3-11). Tapi dalam Lukas sendiri kebahagiaan itu diadu dengan kesengsaraan atau kecelakaan (Luk. 6:2426). Sehingga berkat kepada orang miskin diadu oleh respon kecelakaan yang berbunyi: "Tetapi celakalah kamu, hai kamu yang kaya, karena dalam kekayaanmu kamu telah memperoleh penghiburanmu" dalam pasal 6:24. Begitu juga dengan beberapa perumpamaan yang dituliskan oleh Lukas, yaitu perumpamaan tentang orang kaya yang bodoh (12:16-21) dan juga perumpamaan tentang orang kaya dan lazarus (16:19-31). Semua ini barangkali adalah kritikan terhadap orang kaya. ${ }^{16}$

Menariknya, dalam teks Lukas 19:1-9 ini diceritakan bahwa Zakeus adalah seorang pemungut cukai yang di rumahnya Yesus makan bersama.Sebuah hal yang membingungkan jika dilihat pada bagian-bagian lain dalam injil Lukas yang mengkritik orang kaya. Inilah yang menjadi rangkaian injil Lukas untuk memberitakan keselamatan. Diawali dengan perjalanan Yesus memasuki kota Yeriko, disana Zakeus melihat Yesus dan berusaha untuk mendekat. Namun karena badannya pendek dia tidak bisa melihat Yesus. Pada akhirnya dia memanjat pohon. Yesus melihat dan menyuruh Zakeus turun dari pohon itu (19:5-6). Ketika Yesus sampai ke tempat itu, Ia melihat ke atas dan berkata: "Zakheus, segeralah turun, sebab hari ini Aku harus menumpang di rumahmu. Lalu Zakheus segera turun dan menerima Yesus dengan sukacita. Perkataan ini membuat orang banyak

\footnotetext{
${ }^{16}$ Cristopher M. Tuckett, Luke (England: Shelfield Academic Press, 1996), 96.
} 
bersungut-sungut."

Fokus pembahasan pada bagian ini adalah ayat 9 dan ayat 10 yaitu bagian yang menuliskan tentang keselamatan.

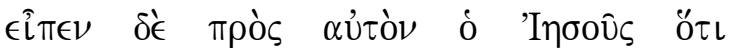

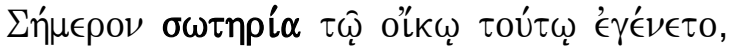

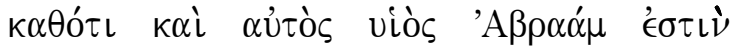
Dalam ayat 9 disebut "Hari ini telah terjadi keselamatan kepada rumah ini, karena orang ini pun anak Abraham." Kata yang dipakai untuk menyatakan keselamatan adalah soteria. Dalam ayat 9 Yesus berbicara "kepadanya" yaitu kepada Zakheus, tetapi ia juga membicarakan Zakheus sebagai orang ketiga. Ayat 9 mempunya fungsi ganda yaitu: pertama, menegaskan kepada Zakheus bahwa tamunya sudah terpenuhi. Kedua, respon Yesus terhadap keberatan orang banyak pada ayat 7 "Tetapi semua orang yang melihat hal itu bersungutsungut, katanya: "Ia menumpang di rumah orang berdosa."

Dalam ayat 9 Yesus menegaskan bahwa Zakheus juga anak Abraham, pernyataan ini menegaskan bahwa janji keselamatan diberikan kepada keturunan Abraham (1:54-55, 72-75, Kis 13:26) dengan demikian Zakeus juga ikut dalam janji keselamatan tersebut walaupun dia telah dikeluarkan oleh Yahudi yang lain. ${ }^{17}$

\footnotetext{
${ }^{17}$ Robert C. Tannenhill, Abingdon New Testament Commentary: Luke (New York:
}

Kata "rumah ini" menunjuk kepada "seluruh keluarga" bukanlah di rumah yang berarti bangunannya. Sedangkan kata "telah terjadi" menunjukkan kehadiran Yesus yang membawa keselamatan. Dimana keselamatan berasal dari Allah melalui Yesus, Sehingga keselamatan terpenuhi ketika Yesus hadir dalam rumah itu. Dan juga penekanan bahwa hal itu telah terjadi.

Pada ayat 9 ini dapat disimpulkan bahwa betapa luasnya kasih karunia Allah dimana Zakheus yang dimusuhi oleh orang Yahudi, yang dicap sebagai seorang koruptor telah bertemu dengan Juruselamat dan hasil dari pertemuan itu berarti bahwa keselamatan itu telah hinggap kepadanya. ${ }^{18}$ Keselamatan kepada rumah ini, berarti bahwa keselamatan tersebut juga untuk setiap orang yang bertemu, yang datang dan menerima diselamatkan. ${ }^{19}$ Perkataan Yesus kali ini ditujukan kepada setiap orang yang hadir dalam rumah tersebut yang diperkirakan ikut mendengar perkataan-perkataan Yesus dan melihat pertobatan Zakheus. Kata 'keselamatan' mengarah pada pemulihan komunitas umat Allah dan realita tersebut menandai

\footnotetext{
Abingdon Press, 1996), 275.

${ }^{18}$ B. J. Boland, Tafsiran Lukas (Jakarta: BPK Gunung Mulia, 2013), 182.

${ }^{19} \mathrm{~J}$. Willcock, The Preacher's Complete Homiletic Commentary: Commentary on the Gospel According to LUKE (Grand Rapids: Baker Books, 1996), 506.
} 
kehadiran Allah dalam hidup mereka.

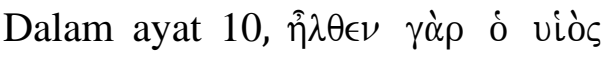

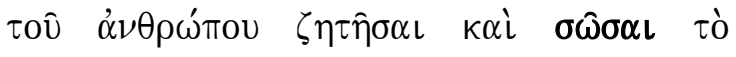

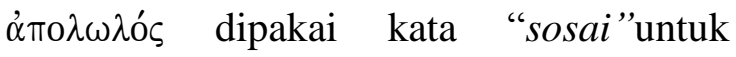
menyebutkan tindakan keselamatan (bentuk Infinitif Aoris Aktif). Yesus menggambarkan misi-Nya yang menekankan tindakan yang telah dilakukan yaitu mencari dan menyelamatkan orang yang hilang. Hal ini mengingatkan pendengarnya tentang perumpamaan Yesus tentang menemukan yang hilang dalam Lukas 15. Keselamatan terhadap Zakeus adalah sesuatu yang tepat bagi Misi yang diberikan Allah kepada Yesus. ${ }^{20}$ Dalam PL keselamatan akan didapat dengan jalan: korban perdamaian, penebusan, dan pembenaran.

Dalam PB, yang menjadi korban pendamaian adalah Yesus Kristus. Ide penyelamatan pada ayat 10 ini adalah sebagai tujuan dari pekerjaan Yesus yang mendunia, tetapi pemikiran ini juga mengarah pada eskatologis. Inilah tujuan Yesus datang ke Dunia dalam karya penebusan-Nya. Sasaran Yesus adalah orang yang terhilang. Sungguh istimewa anugerah ini karena benar-benar kontras dengan pandangan dan kasih manusia. Menyelamatkan yang hilang berarti menyelamatkan siapa saja yang tersesat jalan hidupnya seperti Yesus

\footnotetext{
${ }^{20}$ Tannenhill, New Testament

Commentary: Luke, 276.
}

mengumpamakan sebagai domba yang hilang. Misi Yesus dilakukan melalui inisiatif membangun hubungan dari yang tidak mengenal Allah untuk mengenal Allah. Prinsip paling penting adalah inisiatif Yesus untuk mencari dan menyelamatkan diberikan kepada mereka yang merespon melalui iman. Perkataan Yesus ini merupakan suatu pendeklarasian besar. Pernyataan ini dapat dikatakan sebagai ringkasan dari seluruh kitab "Injil" (yang artinya 'kabar baik'). ${ }^{21}$

Teologi keselamatan di dalam Lukas 19:1-10 adalah keselamatan yang tidakmengenalbatas. Dimana Yesus adalah pusat keselamatan itu. Keselamatan tidak ada batasannya, karena Yesus menjalankan misi yang diberikan Allah tanpa mengenal batas, malah menerobos segala batasan yang dibuat oleh Manusia. Bagi orang Yahudi, tipikal Zakheus yang menjabat sebagai pemungut cukai/pajak adalah orang yang digolongkan jahat. Mengapa? Karena mereka memungut pajak melebihi dari yang seharusnya. Bukan soal memungut pajak, tetapi lebihnya itu untuk diri sendiri bukan untuk pemerintah. Zakheus tahu bahwa dia dicap sebagai seorang koruptor. Pun demikian halnya perilaku Zakheus, keselamatan tetap datang kepadanya ketika ia mengambil sikap melalui imannya kepada Yesus Kristus. 


\section{Implikasi Teologis}

Satu-satunya yang mencatat peristiwa Zakheus bertemu Yesus hanya Injil Lukas. Hal ini menegaskan sesuatu hal yang sangat penting bagi kehidupan umat manusia. Pemahaman umum yang muncul dalam diri kebanyakan orang adalah bahwa orang berdosa tidak akan mungkin memperoleh keselamatan, melainkan akan beroleh hukuman dari Allah. Pemahaman seperti ini berakar dalam kehidupan manusia terutama orang Yahudi. Maka tidak sedikit orang yang bertindak untuk mencapai keselamatan itu. Seakan-akan apa yang mereka perbuat akan membawa keselamatan bagi mereka.

Kondisi ini sudah dimulai sejak perjanjian lama. Alat keselamatan, langsung atau tidak langsung disediakan melalui para bapak leluhur, hakim, pemberi hukum, imam, raja dan nabi. Hukum baik bersifat ritual maupun moral, akibat dosa manusia tidak mampu memberikan keselamatan yang penuh, tetapi menunjukkan ciri dan tuntutan Allah. Kondisi ini juga dalam batas-batas tertentu mengerem kesalahan manusia. Akan tetapi penyalahan moral melahirkan legalisme dua muka, yaitu keterikatan secara lahiriah kepada peraturan-peraturan telah kehilangan kenyataan spiritual yang terdalam, serta pencapaian manusia telah dibeberkan di hadapan Allah dengan tuntutan yang bersifat membenarkan diri sendiri, untuk memperoleh keselamatan.

Lukas memusatkan keselamatan pada Yesus. Dimana Yesus menjadi sumber keselamatan. Penerima keselamatan dimanapun tidak boleh membanggakan diri kepada Allah. Jika keselamatan benar-benar bekerja dalam diri orang-orang percaya, maka persekutuan (koinonia) mereka di dalam roh akan bertambah. Kekuatan dari Tuhan yang secara vertikal bekerja ke bawah, membuat mereka sadar akan dampak "horisontal" atas masyarakat yang harus terjadi karena memiliki keselamatan itu. Mereka yang telah diselamatkan harus mengingat bahwa keselamatan itu bukan usaha melainkan adalah oleh Yesus kristus. Sejarah gereja menunjukkan bagaimana gereja telah belajar dan masih bersaksi tentang keselamatan dalam setiap zaman. Zakheus, seorang pemungut cukai, mencari nafkah dengan mengumpulkan pajak lebih banyak daripada yang seharusnya ia peroleh dari rakyat. Oleh karena hal ini, para pemungut cukai dipandang rendah oleh masyarakat. Perhatian Yesus terhadap Zakheus menjadi pengingat untuk membawa Injil kepada orang yang ditolak oleh masyarakat, karena semua orang sedang terhilang dan memerlukan keselamatan. 
Implikasi Dalam Pendidikan Agama Kristen

Topik keselamatan merupakan materi yang tidak terpisahkan dalam pembelajaran Pendidikan Agama Kristen (PAK) di sekolah. Hal inikarena topik keselamatan menjadi inti dari setiap penyampaikan nilai-nilai kebenaran dalam pembelajaran PAK di sekolah. Hal ini tertuang dalam tujuan pembelajaran PAK itu sendiri. Tujuan pembelajaran PAK adalah untuk mengajak, membantu, menghantar seseorang untuk mengenal kasih Allah yang nyata dalam Yesus Kristus, sehingga dengan pimpinan Roh Kudus ia datang ke dalam persekutuan yang hidup dengan Tuhan. ${ }^{22}$ Hal ini dinyatakan dalam kasihnya terhadap Allah dan sesama, yang dihayati dalam hidupnya sehari-hari, baik dengan kata-kata maupun perbuatan selaku anggota tubuh Kristus.

$$
\text { Merujuk kepada tujuan }
$$
pembelajaran PAK di atas, menunjukkan bahwa materi keselamatan memuat nilainilai yang membawa peserta didik untuk mengenal dan mempercayai kasih Allah yang menyelamatkan. Guru PAK memiliki peran yang sangat penting dalam menjabarkan konsep dan nilai-nilai keselamatan tersebut. Terumata mempertimbangkan konsep keselamatan

\footnotetext{
${ }^{22}$ Daniel Nuhamara, Pembimbing Pendidikan Agama Kristen (Bandung: Jurnal Info Media, 2009), 31.
}

Injil Lukas 19:1-10 dalam kisah Zakheus. Dimana secara sederhana mengungkapkan bahwa melalui kasih Allah dalam Yesus Kristus, Zakheus mengalami pertobatan dan menerima keselamatan.

Kasih Allah yang menyelamatkan Zakheus dalam Injil Lukas ini, menjadi pokok penting dalam pembahasanpembahasan guru PAK dalam pembelajaran di sekolah. Guru PAK diharapkan mampu menjabarkan nilai-nilai tersebut sehingga mudah untuk dipahami dan diterima oleh peserta didik. Tidak bisa dipungkiri bahwa peserta didik dapat berasal dari berbagai denominasi gereja yang berbeda satu dengan yang lainnya. Dari perbedaan latar belakang peserta didik tersebut, kemungkinan terdapat perbedaan konsep tentang keselamatan. Untuk itu, guru PAK perlu mempertimbangkan perbedaan tersebut dan berupaya sebaik mungkin dalam memberikan pengajaran terkait topik keselamatan.

\section{KESIMPULAN}

Pokok pembahasan tentang keselamatan dalam Injil Lukas 19:1-10 melalui kisah Zakheus, dapat disimpulkan beberapa hal sebagai berikut: Pertama, berkaitan dengan keselamatan umat manusia. Keselamatan dari Perjanjian Lama hingga Perjanjian Baru adalah 
keselamatan dari Allah Sendiri yang artinya Allah yang berinisiatif untuk melaksanakan misi penyelamatan itu. Manusia selalu berusaha untuk melunakkan hati Allah karena keberdosaanya melalui ritual, korban, amal, namun semuanya gagal total. Dalam hal ini Allah menunjukkan kasih-Nya kepada manusia seperti yang terjadi pada pribadi Zakheus. Kedua, manusia tidaklah selamat atas usahanya sendiri tetapi lebih kepada Karya Allah yang bertindak aktif dalam karya keselamatan. Tidak boleh seorangpun menyombongkan diri atas karya Allah tersebut, karena itu murni anugerah Allah. Pada kisah penyelamatan Zakheus yang dituliskan oleh Lukas sangat jelas memberikan gambaran bagaimana proses keselamatan itu terjadi. Ada hubungan kausalitas yang terjadi disana. Yesus menawarkan keselamatan dengan anugerah-Nya dan Zakheus menerima anugerah itu dengan hati yang terbuka.

Ketiga, Injil Lukas jelas memuat teologi keselamatan yang bersifat Universal. Dalam hal ini keselamatan tidak boleh dipahami secara parsial. Hendaknya umat Kristiani memahami akan hal ini sehingga tidak mempersempit karya penyelamatan yang dikerjakan oleh Allah melalui Yesus Kristus. Karya penyelamatan Allah tidak terbatas bagi orang-orang Kristen (karena kelahiran) saja, namun keselamatan tersedia secara universal bagi siapa saja yang percaya dan menerima Dia sebagai Tuhan dan Juruselamat. Keempat, keselamatan tidak memandang batasan tetapi keselamatan dari Allah melalui Yesus Kristus menerobos batasan-batasan yang dibuat oleh manusia. Hal ini sering sekali terjadi, entah dalam kesadaran ataupun diluar kesadaran, manusia terlalu mudah menjadi hakim bagi sesamanya. Kisah yang dicatat dalam Injil Lukas berkaitan dengan kisah Zakheus pemungut cukai yang sangat dibenci oleh bangsanya. Namun oleh karena kasih Allah, ia diselamatkan.

Kelima, penilaian manusia bukanlah penentu terhadap keselamatan melainkan hanya Allah sendiri. Manusia tidak diberikan mandat oleh Allah untuk memutuskan siapa yang berhak menerima keselamatan dan siapa yang tidak selamat. Tugas orang percaya di dunia bukan untuk menilai dan memberikan penilaian melainkan menjadi garam dan terang dunia. Keenam, prinsip dan konsep keselamatan dalam penelitian ini dapat menjadi pertimbangan dalam materi pembelajaran Pendidikan Agama Kristen di sekolah. Artinya, guru PAK dalam mengajar peserta didik di kelas yang notabene berasal dari berbagai denominasi gereja dapat memberikan pengajaran yang tepat terkait topik keselamatan. 
Kesimpulan penelitian di atas adalah hasil kajian analisis peneliti yang terbatas. Peneliti menyadari masih terdapat kekurangan dan kelemahan dalam kajian penelitian ini. Untuk itu, peneliti sangat terbuka dan memberikan saran kepada peneliti-peneliti lain untuk melakukan penelitian lebih lanjut tentang topik penelitian ini. Besar harapan peneliti agar penelitian ini memberikan sumbangsih terkait wawasan teologi, serta memberikan dasar pemikiran dalam kajian-kajian penelitian berikutnya.

\section{DAFTAR PUSTAKA}

Boland, B. J. Tafsiran Lukas. Jakarta: BPK Gunung Mulia, 2013.

Carlson, G. Raymond. Keselamatan. Malang: Gandum Mas, 1983.

Duyverman, M. E. Pembimbing Ke Dalam Perjanjian Baru. Jakarta: BPK Gunung Mulia, 2002.

Fohrer, Georg. Theological Dictionary of The New Testament. Michigan: Grand rapids, 1971.

Haldenguis, J. L. Ensiklopedia Alkitab Masa Kini Jilid II. Jakarta: Yayasan Komunikasi Bina Kasih, 2008.

Handayani, Dessy. "Tinjauan Teologis Konsep Iman Dan Perbuatan Bagi Keselamatan." EPIGRAPHE: Jurnal Teologi dan Pelayanan Kristiani 1, no. 2 (2018): 91.

Jura, Demsy. “Kajian Soteriologi Dalam Teologi Universalisme, Calvinisme Dan Armenianisme Serta Kaitannya Dengan Pembelajaran Pendidikan Agama Kristen." SHANAN: Jurnal Pendidikan Agama Kristen 1 No. 2 (n.d.).

Leks, Stefan. Tafsir Injil Lukas. Yogyakarta: Kanisius, 2003.
Manurung, Frans Setiadi. “Teologi

Keramahan Allah: Sebuah Pembacaan Kristologi Lukas." Gema Teologika 3, no. 2 (2018): 185.

Nuhamara, Daniel. Pembimbing Pendidikan Agama Kristen. Bandung: Jurnal Info Media, 2009.

Pangaribuan, Robert. "Menyikapi Perbedaan Pandangan Christology from Above and Christology from Below." SOTIRIA: Jurnal Teologi dan Pelayanan Kristiani 2, no. 1 (2019): 17-20.

Purwantara, Iswara Rintis. "Kritik Hermeneutis Terhadap Interpretasi Soteriologis Perumpamaan Tentang Anak Yang Hilang Dalam Lukas 15:11-32." Prudentia: Jurnal Teologi dan Pendidikan Kristiani 1, no. 1 (2018).

Richaeson, Alan. Salvation Dalam The Interpreter Dictionary of The Bible. New York: Abingdon Press, 1962.

Setiawan, David Eko. "Refleksi Pastoral Terhadap Konsep Keselamatan Dalam Universalisme Ditinjau Dari Soteriologi Kristen." FIDEI: Jurnal Teologi Sistematika dan Praktika 1, no. 2 (2018): 250-269.

Tannenhill, Robert C. Abingdon New Testament Commentary: Luke. New York. Abingdon Press, 1996.

Tuckett, Cristopher M. Luke. England: Shelfield Academic Press, 1996.

Willcock, J. The Preacher's Complete Homiletic Commentary: Commentary on the Gospel According to LUKE. Grand Rapids: Baker Books, 1996.

Zaluchu, Sonny Eli. Biblical Theology: Pembahasan Metodologi Dan Pendekatan Biblika Dalam Membangun Teologi PL Dan PB Yang Alkitabiah. Semarang: Golden Gate Publishing, 2017. 